\title{
Biodiversity Risk Assessment of Protected Ecosystems
}

\author{
Vitalija Rudzkiené ${ }^{1}$, Imantas Lazdinis ${ }^{2 *}$ and Vytautas Azbainis ${ }^{3}$ \\ ${ }^{1}$ Institute of Economics and Business, Mykolas Romeris University \\ ${ }^{2 *}$ Institute of Public Administration, Mykolas Romeris University \\ ${ }^{3}$ Department of Banking and Investments, Mykolas Romeris University \\ cross'ref $\mathrm{http} / / / \mathrm{dx}$. doi.org/10.5755/j01.erem.63.3.4478
}

(Received in May, 2013; accepted in September, 2013)

\begin{abstract}
Forest ecosystems are characterised by the most abundant biodiversity because there are the best conditions for existence of various species of plants, animals and various other organisms there. Generally, in the last decades a lot of attention is given to biodiversity, and scientific research draws attention to an increasing loss of biodiversity. Biodiversity measurements are needed in order to understand biodiversity changes and to control them. Measurements and assessments of biodiversity of ecosystems reveal the condition of an ecosystem of a certain territory as well as create the basis for a strategy of preserving separate species. A lot of indices for assessing biodiversity risk have been created in the last decades. Integrated indices are composed when joining indices, and one of them is the integrated biodiversity risk assessment index NABRAI (National Biodiversity Risk Assessment Index). This article analyses the principles of creating biodiversity risk indices, possible alternatives of components (variables of biodiversity resources, impact and response indices), and their suitability at the national level. Assessment and ranking methodology, adapted for assessment of biodiversity risk of local protected territories and for ranking of territories, is presented. Report data of directorates of Lithuanian national and regional parks are used for the analysis, as well as the data served as a basis to calculate integrated biodiversity risk indices of several protected territories of Lithuania.
\end{abstract}

Keywords: forests, ecosystems, protected territories, indices of biodiversity, biodiversity risk, integrated indices, NABRAI.

\section{Introduction}

It has been determined that the major part of biodiversity of all land ecosystems is in forests. For example, more than $90 \%$ of all land species are found in tropic forests that occupy only $7 \%$ of the surface of the Earth (Ozolinčius et al. 2005). As many species are found also in Lithuanian forests. During recent decades very much attention has been given to biodiversity, and many scientific researches draw attention to an increasing loss of biodiversity (Cincotta et al. 2000, Myers at al. 2000). Biodiversity is an important element of stability of ecosystems. In a healthy ecosystem organisms perform different functions, complementing each other and interacting with neighbouring ecosystems, thus regulating the work of an ecosystem. Since ecosystems consist of many different species, their activity remains stable even in cases when several species are affected or lost. But loss of species is like a warning signal of a possible threat to the whole ecosystem.

A traditional method of preserving biodiversity is creation of the system of protected territories. Such nature networks that connect natural systems stop the threat of disappearance of natural ecosystems, help to sustain ecological connections, and are very important for preserving biodiversity (Belova et al. 2005). But the creation of a system of protected territories does not mean that the threat to biodiversity disappears. Regardless of how good the method of managing protected territories is, most often it is not possible to realize all requirements for protection of species and habitations, and the risk remains. The risk to biodiversity may be analysed from various aspects: the use of natural resources, climate change, environmental pollution, or introduction of new 
species. In any case thorough research and statistical data are necessary for risk assessment.

Although constant discussions are going on in the public space and scientific literature regarding the problems of the decrease in biodiversity, extinction of certain species that has already happened or is going on, and preservation methods, it must be acknowledged that not much statistical data has been collected on biodiversity. As the Eurostat publication "Environmental Statistics and Accounts in Europe" (Environmental... 2010) states, it is impossible to indicate a precise number of species in any region of the Earth, because new organisms are discovered all the time. Some species that are being discovered are old, other species have appeared not so long ago because, due to laws of evolution and natural selection, new species appear all the time. It is not known precisely how many life forms - species there are in the world, but an opinion exists that there may be from 5 to 30 million species, and only 1.7-2 million have been described. Due to the general lack of information, especially on tropical, saltwater, and freshwater species of flora and fauna, a very wide assessment interval appears. As stated in the "Millennium Ecosystem Assessment, 2005" (Millennium... 2005), this area has a very deep need for information that needs to be collected. An opinion exists that Lithuanian biodiversity consists of over 30 thousand species of plants, fungi and animals, and more than 200 species of flora, more than 200 species of fauna, and almost 100 species of fungi are on the verge of extinction and are included in the Red List of Lithuania.

As stated in "Environmental Statistics and Accounts in Europe", 2010 edition, since biodiversity is too complicated for it to be measured exactly, besides, new species are being constantly discovered, therefore surrogate methods of assessing biodiversity are usually applied. The following methods are applied in most cases:

- changes in the number of species on the verge of extinction;

- population tendencies of species that are very widely prevalent and related to certain ecosystems;

- changes of ecosystems and land use or land surface.

In recent decades seeking to create a universal biodiversity assessment system that would be suitable for international assessment, a whole lot of biodiversity risk assessment indices have been suggested. Usually these indices are grouped into three wide categories: indices of biodiversity resources, impact and response (Stork and Samways 1995, Reyers at al. 1998)). Apart from these main index categories McNeely (1996) emphasized the importance of including economic value into biodiversity risk assessment. Usually it is not easy to acquire the economic information, therefore it is often not included in risk assessment.

In order to reach this aim assessment indices of dependence of the variety of species on territory area were analysed. Data of reports from protected
Lithuanian territories were used for the empirical research. Having applied the biodiversity risk calculation methodology, biodiversity risk level and ranks of several national and regional parks of Lithuanian were identified.

\section{The concept of biodiversity}

The term of biodiversity was used for the first time in the seventies of the $20^{\text {th }}$ century, and it has acquired a wide interpretation of several levels in quite a short time. Biodiversity is analysed at several different levels, therefore it is possible to find many definitions for this term in scientific literature. The definition of biodiversity that is used most often is the one that was presented in the UN Convention on Biodiversity (05-06-1992, Rio de Janeiro; valid from 29-12-1993): biodiversity means "the variability among living organisms from all sources, including, inter alia, terrestrial marine, and other aquatic ecosystems, and the ecological complexes of which they are part: this includes diversity within species, between species and of ecosystems." Three levels of biodiversity are distinguished according to this definition:

1. Genetic diversity: it encompasses all the information, passed down from one generation to another, existing in the genes of all living organisms. Maintenance of genetic biodiversity is a basis for natural selection, adaptation and survival.

2. Species diversity: it shows the diversity and relative abundance (distribution) of individuals of different species, present in a certain territory. The term of biodiversity is one of the main indices of the quality of ecosystems. Although the species' biodiversity index is often used as the measure and synonym of species diversity, it does not fully reveal the much more complex index of ecological diversity (Magurran 2004).

3. Ecosystem diversity: it associates the diversity of a certain habitat (forests, deserts, waters) of an ecosystem with the species, existing in the ecosystem. Ecosystems constitute complex networks among biotic (living) components such as plants and animals, and abiotic (non-living) components such as air, sunshine, minerals and nutrients. The diversity existing inside a natural ecosystem is the guarantee of its stability, and artificial changes of an ecosystem decrease its biodiversity and increase its instability.

According to (Global... 2005) composition, structure and functions are aspects of biodiversity of ecosystems.

Diversity of territorial distribution of ecological communities is qualitatively different from spot diversity of separate locations because it shows collective adaptation of a species to various environmental conditions. Therefore much effort is given to assess ecosystems' biodiversity, related to such important ecological constructions as multidimensional factor space, models of density functions of species distribution in this hyperspace 
and competitive struggle of populations for environmental resources.

Robert H. Whittaker (1975) compiled a system of terms and their verbal conception that summarized various types of ecological biodiversity. Letters of the Greek alphabet are used for marking types. This classification was later supplemented and developed by other authors (Bunce RGH et al. 2002; Matthews et al. 2001; Huston 1996)

Diversity inside a habitat is called alpha $(\alpha)$ diversity: it defines the interaction of a group's organisms and competition for the same resources or use of the same environment. Alpha diversity is assessed locally, in a certain place, and shows the number of species of an ecosystem (species richness).

Inter-habitat diversity or beta $(\beta)$ diversity defines the relation of organisms with spatial heterogeneity. Big beta diversity means a small similarity among the composition of different habitat species. Beta diversity is often expressed by the similarity index of communities of different species of the same geographical locality. Assessing this type of diversity measurements are made in two or several localities, and the quantity of all unique species of each ecosystem is calculated and compared. The richness of species of one habitat may be compared in various time intervals. Such comparison allows revealing the stress felt by analysed species or an impending extinction.

Gamma $(\gamma)$ diversity measures the general biodiversity of different ecosystems of a big region (Hunter 2002). changes.

Delta $(\delta)$ diversity is determined by climate

The importance of biodiversity is emphasized by different levels of its assessment. Genetic biodiversity constitutes a separate science, and a lot of attention is given to its definitions, analysis and detailed mathematical models in the abundant literature of this area. But genetic diversity is not analysed in this article.

Other higher hierarchical layers (biodiversity of species and ecosystems) encompass research of diversity of separate individuals and their accumulation in certain levels.

\section{Material and methods}

Assessment of biodiversity changes and risk control requires biodiversity measurement. Measurements of biodiversity of ecosystems reveal the condition of an ecosystem of a certain territory as well as form the basis of the strategy for preserving separate species. But it is impossible to research the populations of all species of an ecosystem, and the quantity of observed species is not linearly related to the sample size. The observed species quantity depends on the sample size and density of individuals (Gotelli, Colwell 2001). The problem of sample selection at a certain moment of time has been widely analysed, but the problem of distribution density of individuals remains complicated, although it is being solved. Therefore assessment and comparison of biodiversity as a fundamental characteristic of ecosystems is a nontrivial statistical problem.

One of the main indices of ecosystem biodiversity is species richness, which is measured by the total number of species, existing in an ecosystem. The bigger the number of species, the bigger possible inter-species interaction, the bigger amount of energy is transmitted, the better food provision is, niches are used etc. When assessing the number of species living in the ecosystem several indices and methods are applied: the index of the number of species, the rarefaction method and indices of species diversity.

Mathematically the index of the number of species seeks to prognosticate the asymptote of the cumulative function of species. But this index is sensitive to sample intensity (the measured part of the population), so the procedure of sample rarefaction is applied. The rarefaction procedure encompasses repetitive research of accidental sample and smooth cumulative species curve that is designed according to the research. Then species richness is compared according to all areas in that point of the curve that corresponds to the number of individuals in the area with the smallest sample intensity. Since the observed quantity of species is a biased estimation of the real quantity of species, the quantity of species, calculated with the help of rarefaction, is usually smaller that the true quantity of species in an ecosystem.

Species diversity indices are alternatives for assessing species richness. A whole lot of popular indices have been created for this aim, and these indices are based on theories of entropy or dispersion. These indices are also sensitive to sample intensity.

Comparison of species richness (quantity) of two or more territories seems a simple task, but due to the sample bias it becomes more difficult than it seems. If it is impossible to measure all species that live in these areas, how can their numbers are compared? When comparing more than two areas often multidimensional statistical ordination and classification methods are applied. Ordination methods may be understood as a synonym of multidimensional gradient analysis. Methods of ordination and classification (clusterization) are the two main groups of multidimensional methods, applied for comparison of species richness of several territories. Classification is grouping of species or sample elements, and ordination is understood as "ranking" in the direction of the gradient of species or sample elements. One of the oldest and simplest methods of classification is the principal component analysis (PCA).

The main factors that have a negative influence on biodiversity are population density, landscape transformation, degradation and habitat fragmentation. Response factors show efforts to perform biodiversity conservation and harmonious use of natural resources. Having joined these contradictory factors into one index a global biodiversity assessment index NABRAI (National Biodiversity Risk Assessment Index) was created (Reyers at al. 1998, Reyers and James 1999). This 
index was created seeking to rank countries according to the experienced biodiversity risk. The impact variables applied in the NABRAI index are the number of endangered species, the density of human population, and big serenity disturbance. Resources' variables are species density, percent of endemic species, and measure of small disturbance intensity. Response variables are the budget part assigned for conservation, information collection, and biodiversity conventions (Reyers at al. 1998). Lack of financial resources and insufficient qualification of personnel are the main reasons that impede successful implementation and coordination of conservation services (Wynberg 2002); this can be applied also at the municipal level. Conservation priorities of municipalities as well as of the government should firstly be directed toward the increase in the value of biodiversity.

Population density and the change of population density are applied as one of the most important impact indices (Reyers at al. 1998; Cincotta et al. 2000; Veech 2003). These indices are not universal, and often they cover up general change tendencies. For example, small population density of certain localities cannot show the intensity of the use of natural resources in these localities because due to contemporary technological development possibilities natural resources can be used also by people, who live tens or hundreds of kilometres away (they can come to gather herbs, mushrooms etc). Landscape degradation and fragmentation show information about the localities' physical state and conditions, those appear more due to social, economic, and political as well as biophysical reasons. Ecosystems are changed or transformed by the following human activities: excess quantity of cattle, cultivation, foresting of grasslands and urbanisation.

Since the NABRAI index is intended directly for application at the international level, when applying it to the assessment of a country's inside situation alternatives for biodiversity resources, impact and response variables that would be suitable at the national level must be chosen. Three groups of national indices were formed for the calculation of the NABRAI index for biodiversity assessment.

Group I - impact indices:

1. Density of permanent population: the number of inhabitants, who have declared their residence in the protected territory, in $1 \mathrm{~km}^{2}$,

2. Change of the density of permanent population: the change of the number of inhabitants, who have declared their residence in the protected territory over a certain period of time, in $1 \mathrm{~km}^{2}$,

3. The number of homesteads: the total number of homesteads in the protected territory, in $1 \mathrm{~km}^{2}$,

4. The change of the number of homesteads: the change of the total number of homesteads in the protected territory over a certain period of time,

5. Transformed territories: the percent of land that has been transformed due to cultivation, foresting, or industrialisation,

6. Vanishing species: the total number of species included in the Red List,
7. Disturbance of serenity: the total number of visitors.

Group II - resources' indices:

1. The total amount of species: the total amount of species of the ecosystem,

2. The amount of endemic species: the total amount of endemic species of the ecosystem.

Group III - response indices:

1. Research and monitoring: research of landscape and biodiversity, monitoring,

2. State budget resources: state budget resources allocated in 2010 for $1 \mathrm{~km}^{2}$,

3. Municipality budget resources: municipality budget resources allocated in 2010 for $1 \mathrm{~km}^{2}$,

4. Resources from the EU and other international funds: resources for implementation of international programmes in 2010 for $1 \mathrm{~km}^{2}$.

State national and regional parks take up the biggest areas of the system of protected territories of Lithuania, and they cause the most disputes, therefore further empirical research was limited only to these two categories of the system of protected territories of Lithuania. Parks of both types compose a geographical unit of a small extent with a local geographical centre that may be formed by a city, a town, or a country village.

The main aim of this article is to analyse perspectives of application of the global biodiversity assessment index NABRAI (National Biodiversity Risk Assessment Index), based on its methodology and application principles, when assessing Lithuanian protected territories.

Three national parks that represent three main ethnographical regions of the country were chosen for the empirical research (Baškytė R. et al. 2006) Aukštaitija National Park, Dzūkija National Park and Žemaitija National Park, and three regional parks that represent the same regions - Asveja Regional Park, Kurtuvènai Regional Park and the Nemunas Loops Regional Park. The Trakai Historical National park and the Kuršių Nerija National Park were rejected due to their particularity.

Since differences between analysed protected territories are big, and analysed samples are very short (sample size $n=6$ ), another method was chosen instead of ranking that allows us to express differences between variables more precisely by standardizing them, i.e. transforming into a scale $[0 ; 1]$ according to the formula:

$$
i_{p}=\frac{p_{f a k t}-p_{\min }}{p_{\max }-p_{\min }}
$$

where:

$\begin{array}{ll}i_{p}- & \text { scale index; } \\ p_{\text {fakt }}- & \text { factual value of the index in a certain } \\ & \text { territory; } \\ p_{\min } \text { and } p_{\max }- & \begin{array}{l}\text { minimum and maximum value of } \\ \text { each index, correspondingly (border } \\ \text { values). }\end{array} \\ \text { In the analysed case the impact index consists of }\end{array}$ the following variables: 
$P R=(g t+s r d) / 2$

where:

PR - impact variable;

$g t-$ density of permanent population, unit $/ \mathrm{km}^{2}$;

$s r d$-part of the number of protected species from the total number of species:

The resources variable consists of: total index of species richness (bri) and intensity of small serenity disturbance $(i t i)$. If we relate serenity disturbance to the number of visitors, this index would be conversely proportional to the number of visitors, i.e. $i t i=1-l s$ :

$S T=(b r i+i t i) / 2$

where:

ST - resources variable;

bri - total index of species richness;

$i t i$ - intensity of small serenity disturbance.

The response index $R E$ consists of: $v b l-$ resources from the state budget, esl-resources of the $\mathrm{EU}$ and other international funds, and $t m$ - monitoring of landscape biodiversity:

$$
R E=(v b l+e s l+t m) / 3
$$

where:

$\mathrm{RE}$ - response index;

$v b l$-resources from the state budget;

esl-resources of the EU and other international funds;

tm - monitoring of landscape biodiversity.

The main data source is reports for 2010 from the analysed national and regional parks that were presented by the parks to the State Service for Protected Areas under the Ministry of Environment. Data of these reports constituted the basis for the research of empirical biodiversity resources, impact and response indices.

\section{Results}

When assessing data precision and reliability, peculiarities of the researched period of time should also be evaluated. The countries of transitional economies (such as the Baltic States) differ from traditional economies with established political and economical environment. Finished or ongoing processes of transition from a planned and closed system to an open economic system of the free market caused very quick changes in the social-economical life of Lithuania. Together with structural economical changes characteristic of the contemporary postindustrial world (decreasing agricultural and industrial manufacture and an increasing amount of services) some changes had strong negative economic and social outcomes. They were expressed by a high level of unemployment, an increasing social differentation and emigration. But positive results of decreased impact of human activities on natural environment and the living nature are also obvious: due to decreased production agricultural pollution decreased, and areas of protected territories became bigger.

Due to speedy social changes statistical data change and grow old very quickly. Because of big emigration that is especially fast in the country regions, data presented by administrations of national and regional parks on the number of permanent population raise serious doubts. It is difficult to determine an exact number of inhabitants due to big movement of inhabitants, re-selling of homesteads and the seasonal way of life. As research shows, Lithuanian villages are quickly becoming empty. It was noted in the 2005 report of the UNDP project performed in Lithuania "Preservation of Biodiversity in Lituanian Swamps - Analysis of Planned Visitor Streams and Possible Impact Assessment of the Ecological-Cognitive Trail Planned in the Girutiškis Reserve in the Labanoras Regional Park": "Dismissing the population of the biggest village Labanoras, which is often called a town, average number of inhabitants of villages of the southern part does not exceed 7 inhabitants. Bigger villages are the following: the town of Labanoras, the villages of Padumblè, Lakaja and Januliškis. More than $75 \%$ of the population are retired, and only $10 \%$ of the population are employable." The tendencies have not changed since 2005 , and the number of permanent population in villages of protected territories was constantly decreasing. This fact cannot be seen from the presented reports because data of a population census that took place a long time ago is used as a basis.

The decrease in the number of permanent population is especially important because it is directly connected with transformation and degradation of territories. At the time when the territory was incorporated into the system of protected territories, only several homesteads in the villages of these territories belonged to city-dwellers. Permanent inhabitants of villages raised cattle, grew potatoes, grains and vegetables in their small farms. Thus a part of the lands of the protected territories were cultivated, a part was pastures, and hayfields formed another part. As the number of permanent inhabitants dwindle, areas of farmland fall away, and meadows grow over with grass. Thus, territory transformation and degradation happens. But this is not seen from the data presented by park adminsitrations.

Data on the number of homesteads is not informative if the number of permanent population is not known. City-dwellers do not lead economical activities when they buy a homestead, and thus their impact on the environment is very small - a lot smaller than that of permanent village inhabitants. But as they do not lead economical activities, citydwellers also do not contribute to the maintenance of the landscape that has formed historically.

The quantity of vanishing species is the number of protected species of animals, plants and fungi that are mostly listed in the Red List of Lithuania. 
Since the sequences of analysed data are very short (sequence length $n=6$ ) most analysis methods that are usually used in this case (data collinearity, normality validation, dimension reduction, identification of latent factors) had to be rejected.

Since the number of identified species is asymptotically related to the territory size, instead of a number of species in one square kilometer adapted Margalef index of species biodiversity (Margalef 1958) was calculated, here:

$d_{M g}=\frac{S-1}{\ln N}$

where:

$S$-number of species;

Table 1. Initial data. Source: Activity reports of the park directorates for 2010

\begin{tabular}{|c|c|c|c|c|c|c|}
\hline Index & $\begin{array}{l}\text { Asveja } \\
\text { Regional } \\
\text { Park } \\
\end{array}$ & $\begin{array}{l}\text { Kurtuvėnai } \\
\text { Regional } \\
\text { Park } \\
\end{array}$ & $\begin{array}{l}\text { The Nemunas } \\
\text { Loops } \\
\text { Regional Park } \\
\end{array}$ & $\begin{array}{l}\text { Aukštaitija } \\
\text { National } \\
\text { Park } \\
\end{array}$ & $\begin{array}{l}\text { Dzūkija } \\
\text { National } \\
\text { Park } \\
\end{array}$ & $\begin{array}{l}\text { Žemaitija } \\
\text { National } \\
\text { Park } \\
\end{array}$ \\
\hline Total area of the territory, $\mathrm{km}^{2}$ & 122.1 & 172.7 & 253.5 & 410.6 & 585.2 & 219.0 \\
\hline $\begin{array}{l}\text { Density of permanent } \\
\text { population, unit } / \mathrm{km}^{2}\end{array}$ & 6.2 & 7.0 & 64.3 & 9.1 & 5.9 & 14.6 \\
\hline $\begin{array}{l}\text { Total number of protected } \\
\text { species }\end{array}$ & 106 & 158 & 192 & 221 & 274 & 237 \\
\hline Index of protected species & 21.9 & 30.5 & 34.5 & 36.6 & 42.8 & 43.8 \\
\hline Number of visitors per $1 \mathrm{~km}^{2}$ & 21.7 & 96.5 & 158.9 & 16.6 & 24.7 & 471.9 \\
\hline Total number of species & 1973 & 2845 & 2770 & 4529 & 3879 & 4428 \\
\hline Total index of species & 410.4 & 552.1 & 500.2 & 752.5 & 608.6 & 821.5 \\
\hline $\begin{array}{l}\text { Percentage of the number of } \\
\text { protected species from the total } \\
\text { number of species }\end{array}$ & 5.37 & 5.55 & 6.93 & 4.88 & 7.06 & 5.35 \\
\hline $\begin{array}{l}\text { Research and monitoring, } \\
\text { number of subjects, units }\end{array}$ & 3 & 13 & 7 & 6 & 18 & 13 \\
\hline $\begin{array}{l}\text { Research and monitoring, units } \\
\text { per } 1 \mathrm{~km}^{2}\end{array}$ & 0.025 & 0.075 & 0.028 & 0.015 & 0.031 & 0.059 \\
\hline $\begin{array}{l}\text { Resources from the state } \\
\text { budget per } 1 \mathrm{~km}^{2}\end{array}$ & 2048.8 & 2737.2 & 1427.3 & 3158.3 & 2168.0 & 4334.8 \\
\hline $\begin{array}{l}\text { Income from provided services } \\
\text { per } 1 \mathrm{~km}^{2}\end{array}$ & 8.5 & 565.0 & 1.5 & 135.6 & 352.5 & 149.4 \\
\hline $\begin{array}{l}\text { Resources from EU and other } \\
\text { international funds per } 1 \mathrm{~km}^{2}\end{array}$ & 0 & 11350.6 & 0 & 2849.5 & 0 & 15934.6 \\
\hline
\end{tabular}

Income received from provided services is very small when compared with other resources, therefore its assessment was rejected.

The application of NABRAI index was done in steps. First, having applied the formula (1), data was transformed (Table 2).

As can be seen from Tables 1 and 2 some data are missing for a full biodiversity assessment: the change of the number of population, the size of transformed territories and the number of endemic species. The results of calculating impact, resources, and response indices are presented in Figure 1.

As seen from Figure 1 the data of the presented reports show that the Nemunas Loops Regional Park experiences the biggest impact on biodiversity. This is determined by a big density of permanent population. Aukštaitija National Park is distinguished by the
$N$-total number of individuals;

ln -logarithm (base $e$ ).

When calculating this index territory area was assessed instead of the number of individuals $N$. This change was performed on the basis that the total number of individuals could be related to the territory area with the help of the logarithm function (Gleason 1922; MacArthur, Wilson 1967).

Data received from the reports from the directorates of national and regional parks of Lituania were used for the analysis (Table 1). 
Table 2. Data transformed into a scale $[0 ; 1]$

\begin{tabular}{|c|c|c|c|c|c|c|}
\hline Index & $\begin{array}{c}\text { Asveja } \\
\text { Regional } \\
\text { Park } \\
\end{array}$ & $\begin{array}{c}\text { Kurtuvėnai } \\
\text { Regional } \\
\text { Park } \\
\end{array}$ & $\begin{array}{c}\text { The Nemunas } \\
\text { Loops Regional } \\
\text { Park } \\
\end{array}$ & $\begin{array}{c}\text { Aukštaitija } \\
\text { National } \\
\text { Park } \\
\end{array}$ & $\begin{array}{c}\text { Dzūkija } \\
\text { National } \\
\text { Park } \\
\end{array}$ & $\begin{array}{c}\text { Žemaitija } \\
\text { National } \\
\text { Park } \\
\end{array}$ \\
\hline $\begin{array}{l}g t-\text { Density of permanent } \\
\text { population, unit } / \mathrm{km}^{2}\end{array}$ & 0.00 & 0.02 & 1.00 & 0.05 & 0.00 & 0.15 \\
\hline $\begin{array}{l}\text { sri-Index of protected } \\
\text { species }\end{array}$ & 0.00 & 0.39 & 0.58 & 0.67 & 0.96 & 1.00 \\
\hline $\begin{array}{l}l s-\text { Number of visitors per } \\
1 \mathrm{~km}^{2}\end{array}$ & 0.01 & 0.18 & 0.31 & 0.00 & 0.02 & 1.00 \\
\hline $\begin{array}{l}\text { bri-Total index of species } \\
\text { richness }\end{array}$ & 0.00 & 0.34 & 0.22 & 0.83 & 0.48 & 1.00 \\
\hline $\begin{array}{l}\text { srd - Part of the number of } \\
\text { protected species from the } \\
\text { total number of species }\end{array}$ & 0.23 & 0.31 & 0.94 & 0.00 & 1.00 & 0.22 \\
\hline $\begin{array}{l}\text { tm - Monitoring of landscape } \\
\text { biodiversity, unit } / 1 \mathrm{~km}^{2}\end{array}$ & 0.16 & 1.00 & 0.21 & 0.00 & 0.27 & 0.74 \\
\hline $\begin{array}{l}v b l \text { - Resources from the } \\
\text { state budget per } 1 \mathrm{~km}^{2}\end{array}$ & 0.21 & 0.45 & 0.00 & 0.60 & 0.25 & 1.00 \\
\hline $\begin{array}{l}\text { esl-Resources of EU and } \\
\text { other international funds per } \\
1 \mathrm{~km}^{2}\end{array}$ & 0.00 & 0.71 & 0.00 & 0.18 & 0.00 & 1.00 \\
\hline $\begin{array}{l}\text { it }- \text { Intensity of small } \\
\text { serenity disturbance, } i t i=1-l s\end{array}$ & 0.99 & 0.82 & 0.69 & 1.00 & 0.98 & 0.00 \\
\hline
\end{tabular}

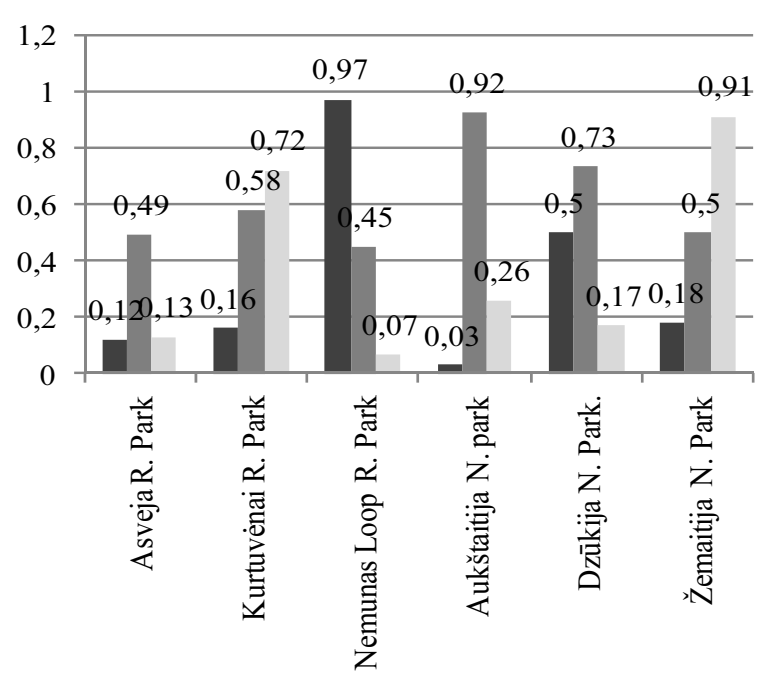

$\square \mathrm{PR}=(\mathrm{gt}+\mathrm{srd}) / 2 \square \mathrm{ST}=(\mathrm{bri}+\mathrm{iti}) / 2 \quad \mathrm{RE}=(\mathrm{vbl}+\mathrm{es} \mathrm{l}+\mathrm{tm}) / 3$

Fig. 1. Values of the components of impact, resources and response of the adapted NABRAI index

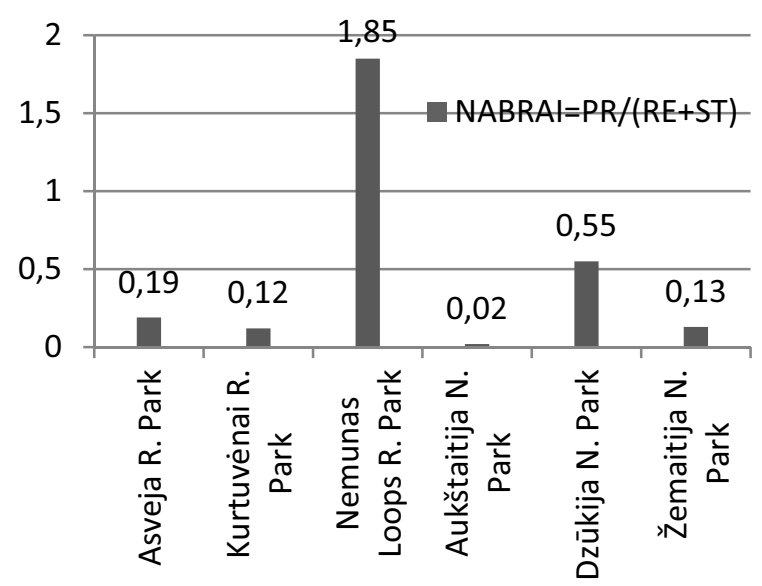

Fig. 2. Values of the integrated biodiversity risk index of protected territories
The best conditions for biodiversity exist in Aukštaitija National Park, Kurtuvėnai Regional Park,

and Žemaitija National Park. But based on the existing data, the calculated index allows us to assess the total biodiversity risk of protected territories.

\section{Conclusions}

1. Since the NABRAI index is intended for direct application at the international level, therefore when applying it to the assessment of the country's inside situation the alternatives, suitable at the national level, of the index variables of biodiversity resources, impact and response should be chosen.

2. State national and regional parts take up the biggest areas of the system of protected territories of Lithuania, and they also cause the biggest amount of disputes, therefore only these two categories were chosen for further research. Due to speedy changes of Lithuanian socialeconomical life, statistical data change and become old very fast. During the last decade the number of permanent population in villages of protected territories has been constantly decreasing. Because of big emigration, which is especially speedy in country regions, data presented by adminstrations of national and regional parks on the number of permanent population raise serious doubts. It is difficult to determine a precise number of inhabitants due to a big movement of population, re-selling of homesteads and a seasonal way of life. This is not evident in the presented reports because they are mostly based on data from an old population census. The decrease in the number of permanent population is especially important 
because it is directly related to transformation and degradation of territories.

3. The calculated index allows us to assess the general condition of biodiversity risk of protected territories. It is determined that the biggest biodiversity risk exists in the Nemunas Loops Regional Park and Dzūkija National Park. The best conditions for biodiversity exist in Aukštaitija National park, Kurtuvėnai Regional Park, and Žemaitija National Park. The calculated values of the adapted NABRAI index are not very precise and final because due to the lack of data a whole lot of important indices (such as changes of the numbers of inhabitants and homesteads, sizes of transformed areas, exact number of total and protected species, and tendencies of their change) were not assessed.

\section{References}

Baškytè, R. ir kt. 2006. Lietuvos saugomos teritorijos [Lithuanian Protected Areas]. Kaunas, Lutute, 98 pp. (in Lithuanian).

Belova O, Karazija S., Šaudyte S. 2005. Description of the historical background that has led to the development of particular national Protected Forest Area Frameworks. Country report - Lithuania.

Bunce, R.G.H, Carey, PO, Elena-ROsello R., Orr J., Watkin, J. and Fuller, R. 2002. A comparison of different biogeographical classifications of Europe. Journal of Environmental Management 65: 121-134. http://dx.doi.org/10.1006/jema.2002.0533

Cincotta, RP., Wisnewski, J. and Engelman, R. 2000. Human Population in the Biodiversity Hotspots. Nature 404: 990-992. http://dx.doi.org/10.1038/35010105

COST E27 Protected Forest Areas in Europe - Analysis and Harmonisation: Reports of Signatory Countries. Vienna, p. 211-231.

Environmental statistics and accounts in Europe. Eurostat Statistical books, 2010.

http://epp.eurostat.ec.europa.eu/cache/ITY_OFFPUB/KS32-10-283/EN/KS-32-10-283-EN.PDF

Gleason, H. A. 1922. On the relation between species and $\begin{array}{llll}\text { area. Ecology } & \text { V. }\end{array}$ http://dx.doi.org/10.2307/1929150

Global Earth Observation System of Systems (GEOSS). 2005. Group on Earth Observation. ESA Publication Divisions, Netherlands, February 2005.

Gotelli, N. and Colwell, R. 2001, Quantifying biodiversity: procedures and pitfalls in the measurement and comparison of species richness. Ecol. Lett. 4, 379-391. http://dx.doi.org/10.1046/j.1461-0248.2001.00230.x

Hunter, M. Jnr. 2002. Fundamentals of Conservation Biology. (Second Edition). Massachusetts, U.S.A.: Blackwell Science.

Huston, M. A. 1996. Biological Diversity: The coexistence of species on changing landscapes. Cambridge University Press: New York, NY.
MacArthur, R. H. and Wilson, E. O. 1967.The theory of island biogeography. Monographs in Population Biology, N. 1. New Jersey: Princeton University Press,

Margalef, R. 1958. Information theory in ecology. General System: 3:.36-71.

Matthews, J.A., et al. (eds.). 2001. The encyclopaedic dictionary of environmental change. Arnold, London.

McNeely, J.A. (1996). Assessing methods for setting conservation priorities. Paper presented at OECD International Conference on Incentive Measures for Biodiversity Conservation and Sustainable Use, caims, Australia, 25-28 March 1996.

Millennium Ecosystem Assessment (2005). http://www.maweb.org/documents/document.356.aspx.pdf

Myers, N., Mittermeier, RA., Mittermeier, C.G., da Fonseca, G.A.B. and Kent, J.2000. Biodiversity Hotspots for Conservation Priorities. Nature 403: 853-858. http://dx.doi.org/10.1038/35002501

Ozolinčius R. et al. Lietuvos miškai [Lithuanian Forests]. Vilnius, 2005, 147 pp.

Reyers, B, James, A.N., van Jaarsveld, A.S. and Mc Geoch. 1998. National Biodiversity risk assessment: a composite multivariate and index approach. Biodiversity and $\begin{array}{lll}\text { Conservation } & 7(7): & 945-965 .\end{array}$ http://dx.doi.org/10.1023/A:1008881405539

Reyers, B. and James, A.N. 1999. An Upgraded National Biodiversity Risk Assessment Index. Biodiversity and Conservation 8: 1555-1560. http://dx.doi.org/10.1023/A:1008978524975

Valstybinè saugomų teritorijų tarnyba. Saugomų teritorijų direkciju kontaktai [State Service for Protected Areas. Structure and Contacts]. http://www.vstt.lt/VI/index.php\#r/46 $\quad-02 \quad-03-2012$ (in Lithuanian)

Stork, N.E. and Samways, M.J. 1995. Inventorying and monitoring of biodiversity. In: Heywood, V.H. (ed). Global Biodiversity Assessment, p. 453-544. Cambridge University Press, Cambridge, UK

Veech, J.A. METAI. Incorporating Socioeconomic factors into the Analysis of Biodiversity Hotspots. Applied Geography 23: 73-88. http://dx.doi.org/10.1016/S01436228(02)00071-1

Whittaker, R. H. 1975.Communities and Ecosystems. New York, New York: Macmillan Publishing Co.

Wynberg, J. 2002. A Decade of Biodiversity Conservation and Use in South Africa: Tracking Progress from Rio Earth Summit to tje Johannesburg World Summit on Sustainable Development. South African Journal of Science 98: 233243. 
Prof. dr. Imantas Lazdinis - Mykolas Romeris University, Department of Environmental Policy.

Main research areas: Environmental Policy and Management, Management of Natural Resources, Sustainable Development Management and Administration, Forest Policy and Management.

Address: $\quad$ Ateities str. 20, LT-08303 Vilnius.

Phone: $\quad+37052714551$,

e-mail: $\quad$ i.lazdinis@mruni.eu

Prof. dr. Vitalija Rudzkienė - Mykolas Romeris University, Faculty of Economics and Finance Management, Institute of Economics and Business.

Main research areas: Evaluation Indicators and Forecasting of Sustainable Development, Insights of Social-Economic Processes, Application of Multidimensional Statistical Methods and Algorithms for Social Models.

Address: $\quad$ Ateities str. 20, LT-08303 Vilnius.

Phone: $\quad+37052714733$,

e-mail: vital@mruni.eu
Vytautas Azbainis - Mykolas Romeris University, Faculty of Economics and Finance Management, Department of Banking and Investments.

Main research areas: Real Estate Cycles and their Influence on Economic System.

Address: $\quad$ Ateities str. 20, LT-08303 Vilnius.

Phone: $\quad+37052714550$

e-mail: $\quad$ vytautasa@mruni.eu

\title{
Saugomų teritorijų biologinės ịvairovès rizikos vertinimas
}

\author{
V. Rudzkiené ${ }^{1}$, I. Lazdinis $^{2}$, V. Azbainis ${ }^{3}$ \\ Mykolo Romerio universitetas, Verslo ekonomikos katedra ${ }^{1}$, Lietuva \\ Mykolo Romerio universitetas, Aplinkos politikos katedra ${ }^{2}$, Lietuva \\ Mykolo Romerio universitetas, Bankininkystès ir investicijų katedra ${ }^{3}$, Lietuva
}

(gauta 2013 m. gegužès mèn., priimta spaudai 2013 m. rugsèjo mèn.)

Miško ekosistemose, ypač esančiose saugomose teritorijose, didelè biologinė ịvairovè, nes čia yra geriausios sąlygos gyvuoti ịvairių augalų, gyvūnų ir kitų organizmų rūšims. Ši dešimtmetị šioms rūšims skiriama daug dėmesio. Atliekant mokslinius tyrimus, atkreipiamas dèmesys ị tai, kad vis sparčiau nyksta biologinė ịvairovė. Norint suprasti ir sekti biologinės ịvairovès pokyčius, reikia atlikti jos vertinimus. Vertinant ekosistemų biologinę ịvairovę, ne tik aiškèja tam tikros teritorijos būklè, bet ir tai yra atskirų rūšių apsaugos strategijos pagrindas. Šiuo metu jau sukurta daug biologinès įvairovès rizikos vertinimo rodiklių. Juos sujungiant, galima gauti integruotus rodiklius, pvz., integruotą biologinès įvairovès rizikos vertinimo rodikli - Nacionalinị biologinès ivvairovès rizikos vertinimo indeksą (National Biodiversity Risk Assessment Index - NABRAI). Straipsnyje nagrinejjami integruotų vertinimo rodiklių sudarymo principai, galimos jų alternatyvos (ivairovès išteklių, poveikio ir reakcijos kintančiųų rodiklių), naudojamos nacionalinio lygmens saugomų teritorijų biologinès ịvairovès rizikai vertinti. Analizei buvo naudoti kai kurių Lietuvos nacionalinių ir regioninių parkų direkcijų ataskaitų duomenys. 